The Winter Meeting was held at the Moat House International Hotel, Stratford upon Avon on 24th-26th January, 1996.

\section{Business Meeting}

The Business Meeting was held on 25th January 1996 and attended by 80 Members of the College.

\section{Minutes}

The Minutes of the 1995 Winter Business Meeting held on lst February 1995 at the Moat House International Hotel, Glasgow, were approved and signed.

\section{Election of Honorary Fellows}

The following were elected to the Honorary Fellowship:

Professor Per Bech, Professor Anthony Crisp, Lady Ann Parkinson, Professor Sir Leslie Turnberg, Professor John Wing.

\section{Registrar's Report}

Since the summer meeting of the College in 1995 a number of elections have taken place, the results of which were as follows.

Dr P. Hettiaratchy was elected as Vice President to succeed Professor A. W. Clare. Professor D. Cottrell was elected as Sub-Dean and Dr E. Taylor and Dr M. Shooter were elected as Deputy Registrars.

The Mental Health (Patients in the Community) Act 1995 came into force in April this year. The College raised many concerns about this bill during its passage through parliament, some of which were accepted, leading to amendments. Despite continuing scepticism about the effectiveness of the new measures to improve patient and public safety we have cooperated with the drafting of the guidelines which accompany the Act as an amendment to the code of practice.

The College's proposals for revision to the criterla for approval under the 1983 Mental Health Act have been accepted by the Royal College of General Practitioners and the Department of Health and were published as guidance to Health Authorities in April, when the new Health Authoritles Act came into force and lead authorities took over the approval function from old Regions.

Following expressions of concern from ourselves to the Department of Health about managers reviews of detention, a meeting between the College, the Mental Health Act Commission and National Association of Health Associations and Trusts (NAHAT) has been convened.

A meeting took place between ACPO (Assoclation of Chief Police Officers), the Crown Prosecution Service (CPS) and the College officers to discuss the reluctance of the police to charge those who were overtly mentally 111 even when a serlous crime had been committed. The most significant barriers to the change in procedure recommended in the Ritchie report (and supported by the College) were identifled. Further discussions are likely to take place.

The up to date revised Bye-Laws and regulations are now available as a Councll report. Work continues to draft Bye-Law changes accepted last year to effect the establishment of faculties, and the Substance Misuse Section is preparing documentation to support its application to be a recognised speciality of psychiatry. A proposal has been put to Councll for amendments to the divisional structure in England, to bring it into line with the new geography of the Regions, and to take the opportunity to examine the effectiveness of the constitution of the divisional executive committees.

Reports on sexual abuse in psychiatric settings, children's evidence in the courts and on the effects of pornography and violence in the media will be considered by Council.

A working party under the chairmanship of Dr T. Sensky has reported on risk assessment and clinical risk management, giving suggested procedures and will be considered by Councll shortly. Professor T. Burns has begun chairing a working party on siting staffing structure and security of psychiatric units, and Dr Allan House has accepted an invitation to chair a group on standards for a place of safety under the Mental Health Act.

The Public Policy Committee has completed the work of revlewing all out of date policy documents with the exception of five, decisions on which are awaiting further consultation. The President has written to the President of the Chinese Psychiatric Association expressing grave concern about the 
innocently named law on infant and maternal health care. Responses are awaited.

The Report of the Confidential Inquiry into Homicides and Suicides by Mentally III People has been published and we thank Dr W. Boyd for his efforts as the first director. After a recent tendering exercise the future of the Inquiry has been established and will be run by the new director Dr Louis Appleby from Manchester Untversity.

\section{Matters arising}

The President reported that Council was currently considering the document on the Role and Responsibilities of the Consultant. This was expected to be available following the March meeting of Councll.

The President referred to the current widespread concern over psychiatric stafing levels. This had led to discussion with the Department of Health about possible solutions.
The President discussed the serious concerns about the implementation of the Care in the Community programme and its effect both on patients and the morale of psychiatrists. The President reported that the College had recently recetved a resolution from Dr Hollander, seconded by Professor Hirsch, which had not been recelved in time for formal consideration by the Meeting. Dr Hollander was invited to read the Resolution to the Meeting prior to it being submitted to Councll on 29th January 1996. This draft Resolution had been discussed by the Executtve and Finance Committee the previous week and it had been agreed that the President should write to the Secretary of State for Health stating that the College would be putting forward certain proposals to the Annual General Meeting.

Comments on the Resolution were invited from the Meeting which would be taken into consideration in preparing the final draft.

\section{Response from the Secretary of State to the President}

Following the letter from Dr Caldicott to $\mathrm{Mr}$ Dorrell (Psychiatric Bulletin, May 1996, 20, 315) the following response was recelved:

Dear Dr Caldicott: I recognise the concerns you express about the implementation of comprehensive mental health services. As you know, I am conscious of the pressures on mental health services and it was for this reason that I set in train the review started by Gerry Malone's letter to health authorities last August. I announced the conclusions of that exercise last week, and set out a programme of action including extra funding and close monitoring of progress.

I hope that this will have gone some way to address the issues you raised. However, I am well aware that we are not going to resolve all our problems overnight, and there is much still to be done. One of the key issues in this will be planning of the workforce, and I am pleased that my Department is working with the Royal College of Psychiatrists on this.

If you feel that a meeting would be useful, I would be glad to see you.

STEPHEN DORREUL 